\title{
Survival Strategy for Lokan Seekers in Paya Pasir Village, Kec. Marelan, Medan, Indonesia
}

\author{
Ramadani Lubis ${ }^{1}$, Ichwan Azhari Phill ${ }^{2}$, Ratih Baiduri ${ }^{2}$ \\ ${ }^{1}$ Administration staff in Islamic Faculty in Universitas Islam Negeri Sumatera Utara \\ ${ }^{2}$ State University of Medan
}

\begin{abstract}
This study dealt with Survival Strategy for Lokan Seekers in Paya Pasir Village, Kec. Marelan, Medan, Indonesia. This situation explains that the number of women in poverty is still high. The high rate of poverty involving women certainly does not happen on its own, there are many things that must be explored and investigated and discussed about what factors make women and poverty as difficult to reduce and eliminate. The research used was qualitative research with an ethnographic approach. Spradley (1997: 3) argues that ethnography is the work of describing a culture. The main purpose of this activity is to understand a view of life from the perspective of the native population. In result, For parents, especially those who have a low income level, it should make children's education the first, because to improve the standard of living can only be done with education. Good children's education will produce changes in life. Besides that, a child should not be taught or supervised in fulfilling the family's economic needs, so that the child can be more focused in taking his education. With this education, a child can compete in the world of structural work, so as to reduce poverty as in the area of Paya Pasir Village.
\end{abstract}

Keywords : Poverty; woman; survival; ethnographic.

\section{Introduction}

The issue of women is closely related to the issue of poverty. Mainly women who inhabit rural areas in Indonesia are inseparable from poor and all-limited living conditions. There is no exception to the living conditions of women in the country's border areas which are still remote and isolated villages. They live together with nature and make nature a source of livelihood. Women on the border have difficulty accessing higher education. After completing elementary school education, they choose to work in Malaysia, or even get married at a relatively young age. This reality is not a reference in a variety of border area development programs, so that their condition still remains underdeveloped

The thing that cannot be separated is the development of women's studies or gender studies in Indonesia cannot be separated from the development of gender studies in various countries. The 1975 Women's World Conference gave birth to Women in Development (WID) perspective that demanded that there be equal opportunities between men and women in the development process. The involvement of women in the economic sector will increase the economic position of women, so that they believe the status and position of women will increase in the community. The WID concept focuses on changing the situation, which aims to attract and place women in the flow of development. This is done because women are abundant human resources that can drive the wheels of development, provided their abilities are improved (Irfarinda, 2014: 1).

Therefore, the situation and condition when a family is in a state of shortage is one of the driving factors for women to appear as agents of the household economy by doing various jobs outside the home. The role of women is increasingly widespread, when they no longer only act as a mother and wife in the domestic sector but also play a role as a driver of their 
household's economy (Marleni, 2013: 10). So this is where women play a role in meeting family needs, as well as going directly to the work sectors. This was illustrated when the researchers conducted preliminary observations on September 21, 2017, where the researchers saw women working as workers in finding lokan in Paya Pasir Sub-district, Kec. Marelan City of Medan. The work carried out by women in searching for the lokan was driven by an inadequate (poor) family condition, as a result of interviews with researchers with Ita's mother who helped find lokan.

"How is it, sir, I can't just keep quiet at home with a family condition that is in short supply. We are poor, sir, so looking for lokan to sell, then sir because my husband's opinion is not enough. "(Interview, September 21, 2017).

Women and poverty are still in desperate need of attention and solutions, because until now there is still a lot of data that concludes that women and poverty are so high in percentage rates. This situation as with Santi (2007) says according to UN data, one third of the world's population lives below the line poverty and $70 \%$ of the poverty rate are filled by women. BPS (Central Bureau of Statistics) in 1998, more than 79 million people or 40 percent of the population were below the poverty line, many of the poor were characterized by women with low education and even illiteracy.

This situation explains that the number of women in poverty is still high. The high rate of poverty involving women certainly does not happen on its own, there are many things that must be explored and investigated and discussed about what factors make women and poverty as difficult to reduce and eliminate.

The reality is that inequality is still often found, discrimination, violence, and injustice are still experienced by women. Gender issues, career opportunities, structural poverty and cultural parts are inseparable from women and the causes of poverty itself. This issue must certainly be of special concern to all parties (government, academics, politicians and the public), because if not then women's problems and poverty will continue to occur until the next generation of women and the impact will result in women and poverty every time increase.

\section{Literature review}

\subsection{Women}

The definition of women is etymologically derived from the word empu which means "master", that is, the person who is proficient or powerful, head, upstream, who is the greatest. But according to Zaitunah (2004: 19) the word woman comes from the word empu which means valued. Zaitunah explains the shift in terms from women to women. The word woman is derived from Sanskrit, with the basis of the word Wan which means lust, so that the word woman has an interpreted meaning or is a sex object.

But in English wan is written with the word want, or men in Dutch, wun and schen in German. The word means like, wish, desire, aim. The word want in the English form of the past is wanted (needed or sought). So, women are who is being wanted, someone who is wanted. Scientists such as Plato say that women are viewed in terms of physical and spiritual strength and are mentally weaker than men, but these differences do not cause differences in their talents.

While the description of women according to the view based on medical, psychological and social studies, is divided into two factors, namely physical and psychological factors. Lewis (1983) said that poor people are a group that has its own culture of poverty which includes social and economic psychological characteristics. Liberals view that human beings 
are good creatures but strongly influenced by the environment. The culture of poverty is just a kind of realistic and situational adaptation in an environment full of discrimination and narrow opportunities. Radicals ignore the culture of poverty, they emphasize the role of economic, political and social structures, and see that humans are cooperative, productive and creative creatures.

\subsection{Poverty}

Determining poverty there are several criteria for measuring poverty. Tambunan (2001: 52) states that the magnitude of poverty can be measured by or without reference to the poverty line. The concept that refers to the poverty line is called absolute poverty, while the concept whose measurement is not based on the poverty line is called relative poverty. The following is an explanation of the two poverty indicators.

\section{a. Absolute Poverty}

Absolute poverty is a condition where the income of a person or group of people is below the poverty line so that it is insufficient to meet the standard needs for food, clothing, health, housing, and education needed to improve the quality of life. The poverty line is defined as average expenditure or average consumption for basic needs related to meeting welfare standards. This form of absolute poverty is most widely used as a concept to determine or define the criteria of a person or group of people called poor.

\section{b. Relative Poverty}

Relative poverty is defined as a form of poverty that occurs because of the influence of development policies that have not reached all levels of society, causing income inequality or inequality in welfare standards (Tambunan, 2001: 54). Areas that have not been reached by development programs like this are generally known as disadvantaged regions.

\subsection{Survival Strategy}

According to Snel and Staring, the survival strategy is a series of actions that are chosen standardly by individuals and households from the middle to lower socio-economic level. Through a strategy carried out by someone, can increase income through the use of other resources or reduce expenditure through reducing the quantity and quality of goods or services. In addition, the survival strategy applies a double income pattern that is part of economic strategy (Resmi, 2005: 6).

Susilawati (2003: 52) states that to improve living standards by adding types of work and changing livelihood patterns. The double income pattern, which is carried out by women, aims to fulfill the family's economic needs. So with this pattern women can survive with their families in meeting their primary and secondary needs. Women's survival strategies are not only in the economic sector, but are oriented towards the social and cultural sectors.

In the social sector women carry out mutual cooperation activities with men such as making bricks, building houses, motorcycle taxi drivers, participating in welfare institutions such as arisan and others. In the cultural sector women behave and act in the same way as men in meeting economic needs, there is a way for women to survive in the needs of their families.

Regarding women's access According to Dewi, a woman can go directly to the field to practice the knowledge she has obtained. Taylor stated that, the economic marginalization of women is a systematic practice to cover women's access and control of economic resources 
and their management processes. This practice has gotten a systematic status because the forms of marginalization of women's economy in the community have gained political, religious and customary legitimacy that has developed in the community. Women who enter the labor market have a smaller chance of getting jobs than men.

\section{Research Methods}

The research used was qualitative research with an ethnographic approach. Spradley (1997: 3) argues that ethnography is the work of describing a culture. The main purpose of this activity is to understand a view of life from the perspective of the native population. As Malinowski points out, the purpose of ethnography is to understand the point of view of indigenous people, their relationship to life, to gain views on their world (Sparadley, 1997). Qualitative research with an ethnographic approach is a study that describes the situation and conditions that exist in the real field by understanding the perspective of the indigenous people, namely women looking for robberies in poor urban villages. The location of this study was in the Paya Pasir Sub-District, Medan Marelan, and Medan, which has 9 neighborhoods. The selection of the Paya Pasir urban village is a place of research on the grounds that at this location there is a lake where the people around the lake work as fishermen.

A study is in the subject and object of research. According to Idrus (2009: 91) that the subject in the concept of research refers to respondents or informants who want the information to be sought. The object of this research refers to the problem or theme to be examined. This opinion can be concluded that what is meant by individual research subjects, objects or organisms that are used as sources of information needed in research data collection related to the object of research that has been determined.

\section{Discussion}

Life that is lived by women seekers can be said to be a difficult life, because they have difficulty in fulfilling their food needs, it is said to be sufficient for clothing and tertiary needs, but life is chosen because of the compulsion to survive. Lokan women are women who already have a family, so to support and fulfill the family's economic needs, they participate in helping the family's economy.

Abundant marine resources and no more costs in the production of marine products, make women in this area choose to look for marine resources such as lokan as daily work, this is one of the survival strategies that they do. In looking for lokan itself requires expertise and habits based on experience, not obtained through one or two studies, but must be as often as possible, added because looking for lokan is a job that must be cultivated, then inevitably they must be experts in looking for it. Because of the experience that they had before, they could easily find out the position and place where lokan usually hid.

With the development of the times that automatically affect economic life, the work as a locator in particular for women is also increasing, so that with the increase in women seeking lokan influences the production of lokan itself. This can be seen from the comparison of the results of production in the past with the present, the longer the production of lokan, the harder it is to produce, indeed it affects the price given to the production of lokan 


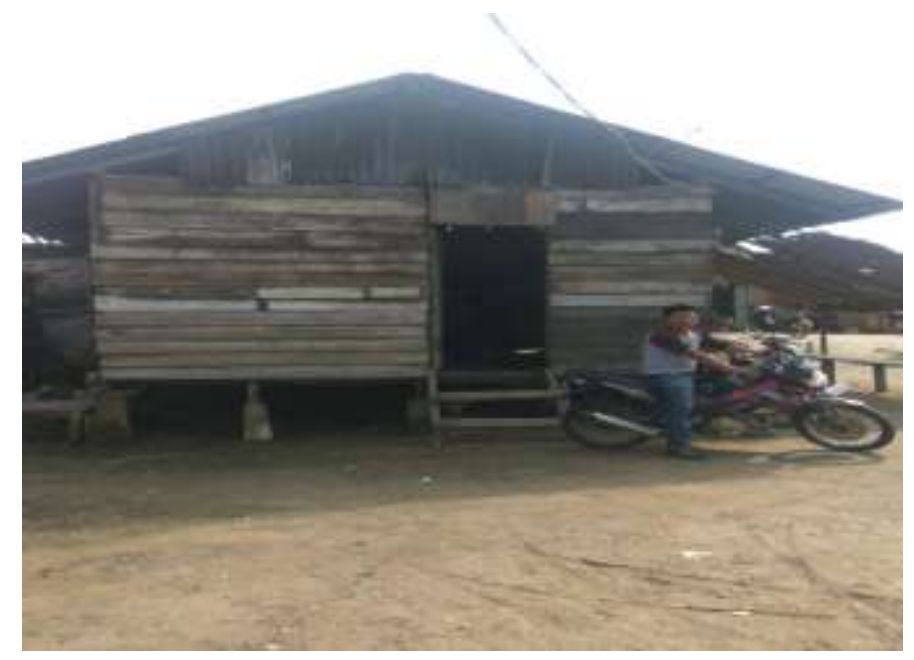

Figure 1. One of the Houses of the Lokan Seekers

Right now, in the sandland area itself, the results of the lokan obtained have a selling price of Rp.20,000/ kg, the price is obtained if the production of lokan is distributed in retail or in other words selling traditional markets in the urban village or by waiting for buyers in the road to the paya pasir village itself, another case when the production of lokan is sold to tokke or penadah which often comes to pick up the yield of lokan, but the price offered by the litter is usually cheaper than the market price, as well as selling to toke, the price offered toke around Rp. 17,000/kg.

When compared with the market price, it is cheaper, but these women who are looking for lokan are sometimes forced to sell toke, this is because there is still business to do first, namely household affairs. With this matter can be seen by researchers that women have a dual role in household life, besides taking care of family affairs, women who seek lokan also participate in fulfilling the family's economic needs which incidentally is the husband's responsibility, this is in line with the statement of Mrs. Marsiah (55 Year) as follows:

"Actually, son, the mother is looking for lokan is forced by circumstances and economic needs, because if you see that you have less income to cover the family's economic needs, not to mention the children who want to go to school and the needs here and there. If you regret it, it's useless ... just have to go through it ... but sometimes it becomes an additional burden, this place has been poorly searched, it's not as easy as it used to be, indeed the price was cheap but delicious because there are a lot of things., plus more and more women are looking for this drill ... not just from this area ... the outside area is coming. Not to mention the problem of selling it ... never mind ... not to mention home business ... sometimes like a machine and this body is going to be ... already taking part in earning a living ... taking care of the household again..that's my life. (Interview, 11-20-2018) "

From the results of the interview above, the researcher concluded that women who seek lokan still have healthy physical abilities, because they have multiple activities or roles in their lives, besides fulfilling their daily economic needs, they also do not abandon their responsibilities as a wife who takes care of home affairs stairs such as cooking and washing. In addition, in the distribution process the results of searching for lokan, sometimes sold alone to get more money that can be used as a family economic enhancer.

Women who seek lokan are included in the family of the lower middle class economy, in addition to working in meeting the domestic needs of households also have a double 
burden. This role is all homework from cleaning the house, cooking, washing, caring for children and all things related to the household carried out by women. When widely reviewed about the role of women as housewives, women have given a very important role in forming harmonious and prosperous families. If seen, there is no higher and lower position between mother and father in the family.

Housewives' jobs in managing houses, cooking, washing, and guiding and caring for children cannot be measured by the value of money. Mother is the most decisive figure in shaping the child's personality; this is because the child's attachment to his mother has started since the child is still in the womb. Likewise, in female households lokan seekers are also still dominated by women's roles who is always responsible for carrying out business in managing his household needs after going to sea. As stated by Ms. Yuni (40 years):

"Usually before the mother goes out to sea, the mother cook first breakfast for the children, but sometimes the mother comes home at $11.00 \mathrm{a} . \mathrm{m}$. still does not eat, also the mother's child, still wants to eat in the dinner and mother. Ready, do you sleep and swing your mother, while you rub or work another house again, if it doesn't really work or not, the house works "(Interview, 11-21-2018)

Double burden is a form of discrimination and is included in gender injustice because some activities are carried out by one gender, namely women. With the development of insights based on this gender approach, the development of women to take part in an activity has developed quite rapidly too, but we need to pay close attention that the development of women in this case does not necessarily change long-lasting social construction, namely the role of women in the scope of taking care of household affairs, but with certain factors, the development of the role of women in nature becomes an added workload that seems excessive. We can see this in various regions, especially in communities with lower middleclass economic life or in other words the poor.

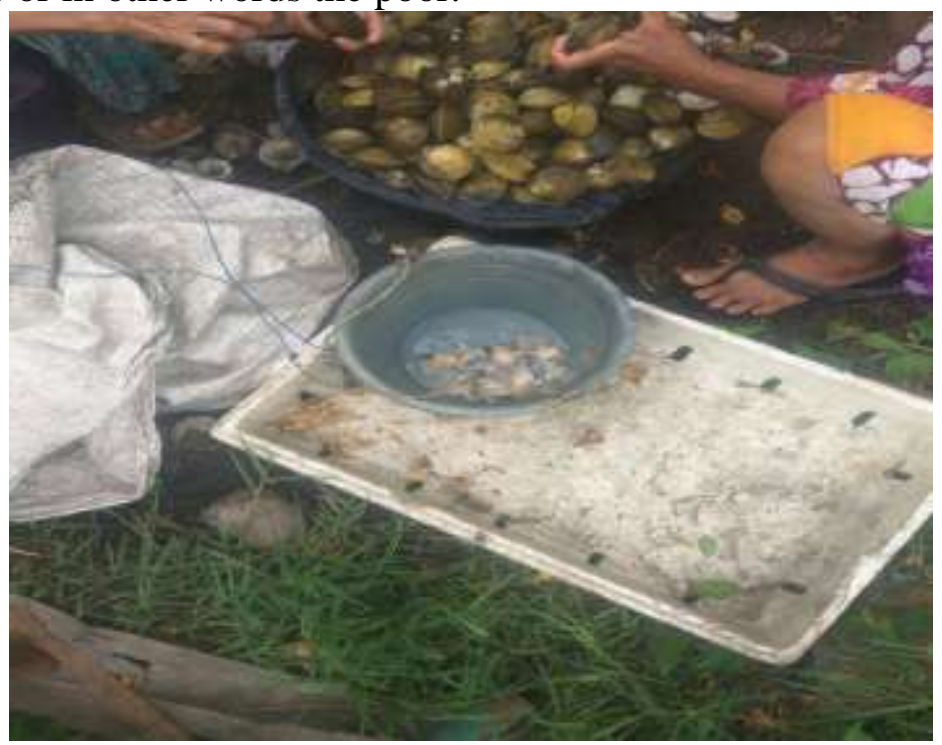

Figure 2. Lokan Cleansing Activity

Women's participation in fulfilling current economic needs is not only demanding equality of rights and obligations, but also expressing functions that have meaning for social life. Women's participation involves roles in terms of tradition and transition roles. The 
traditional or domestic role includes the role of women as wives, mothers and those responsible in managing the household.

While the role of transition includes the understanding of women as workers, community members and development agents. In the transitional role of women as laborers, they are actively involved in economic activities, namely earning a living in various social activities that are in accordance with their skills and education and utilizing available employment, but not a few who are seekers because of lack of skills and low education level .

In addition to looking for lokan which are used as the main jobs of women in the Paya Pasir Village area, they also sometimes do other work besides looking for lokan, because the current results of lokan cannot always fulfill their daily economic needs in full, this is due to an increase in the number of lokan seekers or natural factors that sometimes do not support going out to look for lokan, so they do other work that can produce money, such as searching for used plastic bottles that are washed away in the flow of grooves, washing clothes and shrimp peeler.

This work is done so that the economic needs of at least one day can be covered, so that it does not affect other economic needs, especially for the needs for school fees for children, both the cost and snacks of children who go to school. This strategy is used as the main support for women who seek to survive in the midst of an increasingly difficult economy today.

\subsection{The Origin of the Economic Life of Lokan Seek Women}

The education level of female lokan seekers in the Paya Pasir Village is unable to complete primary school education so that the education of female lokan seekers tends to be quite low, because there are still many of them who are unable to read or write, even though some of them can read, but in the category write them all not smart.

Many factors cause women in this area not to complete their education at least elementary school, this is because at that time school fees were classified as expensive, unlike now where the school fees had already been intervened by the government such as the existence of BOS funds for each educational institution. While the age of women who seek lokan is included in the old category, because many of them are above the age of 35 years, in addition to looking for lokan, the most common work is to peel the shrimp skin. Most of the shrimp comes from the catch of a husband who seeks in the sea or in a groove.

The women who seek lokan in the age of 40 have more experience in searching for and cleaning lokan from their shells. At the age of 45 years, female lokan seekers usually rely heavily on kinship with relatives or neighbors in seeking lokan, because with age they are no longer young, they are limited in accessing appropriate economic resources. Most of the women who work as widows are widows and some are still in the age of having a productive age, because they are married at a young age, but there are also those who are unproductive but participate in fulfilling their needs, because they have no other work than looking for lokan.

The burden borne by women who seek lokan is increasingly heavy due to the large number of dependents such as the economy and the cost of education. This widowed woman who can inherit cultural poverty to her generation, because their children also help work to increase family income, even though at a young age they are required to focus on their education. Even though their children are older and married, they still donate a little money to help their parents. 
The majority of widows are only able to become a shrimp peeler, because of the inability to look for lokan every day. The wages obtained are also less than for families who own boats and looking for shrimp. For those who are still married, some become lokan seekers and help their husbands because they own a boat and usually go to sea. Because of this, for women who are old and do not have a boat, they find it difficult to fulfill their economic needs.

Talking about the life of social beings can not be separated from the name of the economy, the economic needs provide social status in people's lives, there is a need for excess economics that is said to be rich, and there is an economy that is said to be poor. Social status like this is obtained because of the structure and culture in society. Education and skills are the main keys in gaining social status in community life.

Structural poverty is poverty suffered by one community because the social structure of the community is unable to utilize the actual sources of income available to them and structural poverty is poverty that occurs not because of the inability of the poor to work (lazy), but because of the system's inability and social structures in providing opportunities that enable the poor to work (Suharto, 2005: 78). Thus the poverty life of women who seek lokan initially occurs because of the structural poverty, where they do not want to take advantage of sources of income to prepare a better generation, such as preparing education funds and living land.

As a result of the structural poverty, the current generation in the Paya Pasir Village is a community that adopts cultural poverty thinking. Cultural poverty is poverty that arises as a result of the values or culture adopted by poor people, such as laziness, easy surrender to fate, lack of work ethic and so on (Lewis, 1993: 40). Lewis's statement is very precise with the situation seen by researchers in the daily lives of fishing communities, especially women who seek lokan.

They lack work ethic in doing work, even to look for lokan they sometimes see the willingness to go or not, even often they are lazy to go look for lokan even though sometimes natural conditions support, plus if there is a celebration, they hold from morning to evening at the celebration event, even though if they have a work ethic, they can take the time to go looking for lokan first and then come to the celebration. Sometimes they also surrender to fate with statements because parents used to have a low economy, this is like the words of the mother of Gandarea (50 years):

"How else can I do it ... the fate of the body has been like this ... used to be by parents as well as this because of the skills they have ... from the past the parents were also economics like this ... so it was difficult to meet the family economy ... take school fees ... it's difficult ... so this is how it is ... it's like the desire to send your children up high so that you don't like the crew ... even though the economic ability sometimes doesn't support your child ... if you look for lokan, we are also lazy ... depends willing ... even though sometimes the day supports .. yes if the body is lazy it doesn't go go look for lokan ... especially if there is a celebration here..mending to the celebration there ... will meet with other mothers..something if you go look for lokan first .. later the gathering time is also told about ... (Interview, 11-212018)

From the results of the interview above, the researchers concluded that the people here did surrender to the fate of the body, because their parents also had the same fate first, plus their lack of work ethic in their personalities added cultural poverty identity in their social lives. If we look through the interviews, the intentions inside them cross the fate of their descendants, but they cannot do it because of work they think has become friends from birth. 
Especially when viewed, there is a willingness to improve the work ethic to collect preparation for education funds, so the stereotype develops that they do not want to get along and pretend. This is what makes people here, especially women seekers can not get out of the shackles of poverty.

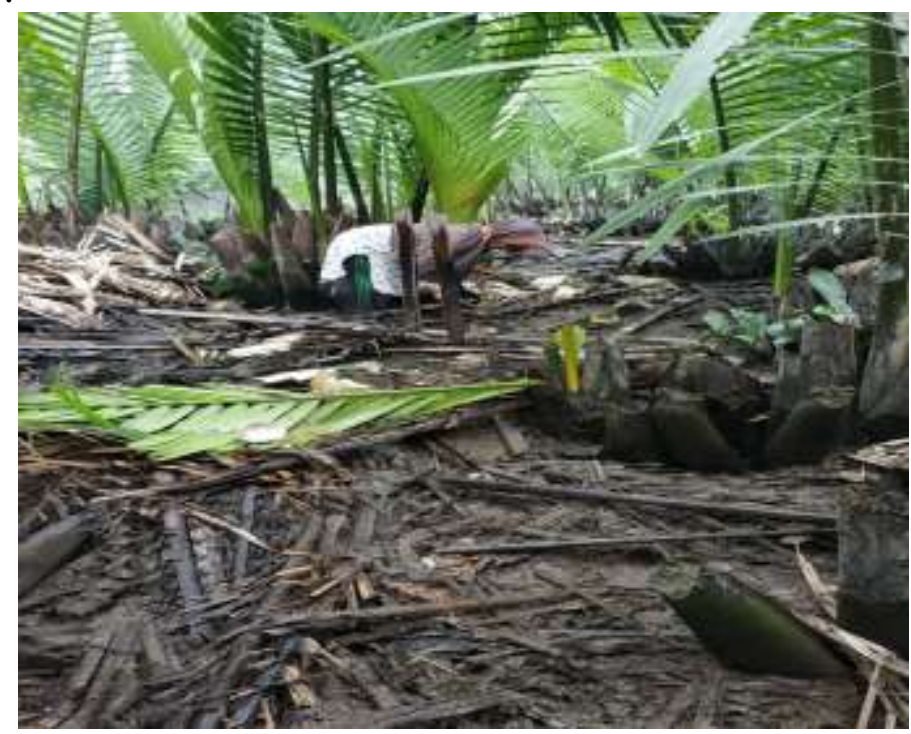

Figure 3. One of the stalls (lokan place of life)

The economic life of the people here, especially women seeking robbery, begins with the absence of their parents' ability to meet economic needs. When they were small they had been introduced to a poor life, because they were taught to help support the family's economy rather than focus on education, in this way, they were more interested in finding money than learning. Besides that, there are also other factors, such as when they were small, they were left by parents either died or divorced, so they did not focus anymore on learning. Because of this they are mostly giving up on the fate of the body.

After being abandoned by male parents, they usually join the mother, and usually the mother will remarry, usually the other man has widowed or old single status. By remarrying, they will not automatically be focused on learning, so they can't help but from a small age they have been invited to help with the family's economy. In the beginning they went to sea only to help a little work for their parents, because this habit made them increase their work to other jobs, such as fishing or lokan.

Coupled with the low level of education and the heavy burden of the family, there are not a few who do young marriages, this is considered to reduce the burden on the family because they already have their own lives.

Whereas in fact it is inversely proportional, the absence of education and skills further increases the level of poverty in this area. In other words, when they do not have a permanent job, they rely on the work of fishermen and women in particular become lokan seekers. As Mrs. Yuni said (40 years old):

"The crew used to be an orphan ... I died when I was a crew of 7 years ... that was the same crew and my brother were 2 years old ... because the economy was difficult ... my mother was married again to the widower ... because married parents married ... the crew don't focus on the school because of the economic situation like that, sir ... at first the crew of working girls became laborers at the yoko factory, before they were married to cover the personal 
needs of the crew ... all of them helped the school add up ... even when they went to sea he also wants to focus on college ... because that is why the crew thinks it's better to get married so that the burden of parents is lighter ... so getting married stops the factory working crew because it can focus on taking care of the household ... another part here, guys, when married bang factory workers ... just another thing from your will ... how come you can work men or not, of course you don't ... just like that, the crew of the migrants join the project to Kerinci ... once a month send money ... if you go home once in four months .. lang, yes, here it is working, he got a project call again, hmmm ... if the call is fast ... if it's long, it's OK for the crew to become the backbone, sir. this is bang ... (Interview, 11-22-2018)

\section{Conclusion}

For parents, especially those who have a low income level, it should make children's education the first, because to improve the standard of living can only be done with education. Good children's education will produce changes in life. Besides that, a child should not be taught or supervised in fulfilling the family's economic needs, so that the child can be more focused in taking his education. With this education, a child can compete in the world of structural work, so as to reduce poverty as in the area of Paya Pasir Village.

\section{References}

Abilawa, MS. 2010. Studi Determinan Karakteristik Rumah Tangga Miskin Provinsi Nanggroe Aceh Darussalam. Thesis. Jakarta: Fakultas Ekonomi. Universitas Indonesia. Bungin, Burhan. 2001. Penelitian Kualitatif. Jakarta: Kencana Prenda Media Group.

Desti, Murdijana. 2005. Kasus Busung Lapar di NTT Bukan Hanya Factor Kemiskinan Tetapi Juga Pengabaian Terhadap Hak-Hak Perempuan. Jakarta: Jurnal Perempuan Juli 2005.

Endraswara. Suwaruli. 2003. Metodologi Penelitian Kebudayaan. Yogyakarta: Gajah Mada University Press

Huberman and Milles. (1992). Analisis Data Kualitatif (tentang metode-metode baru). Jakarta: UI-Press

Irfarinda, Mutiara. 2014. "Analisis Gender Tenaga Kerja Wanita Dalam Partisipasi Ekonomi Rumah Tangga". Departemen Komunikasi dan Pengembangan Masyarakat. IPB. (http://www.skpm.ipb.ac.id, access by11 Juni 2016)

Idrus. Muhammad. 2009. Metode Penelitian Sosial. Yogyakarta: Erlangga

Kusnadi. 2000. Nelayan Strategi Adaptasi dan Jaringan Sosial. Bandung: Humanoira Utama Press.

Lewis, Oscar. 1988. Kisah Lima Keluarga: Telaah-telaah Kasus Orang Meksiko Dalam Kebudayaan Kemiskinan. Jakarta: Obor.

Moleong. 2002. Metode Praktis Penelitian Deskriptif Kualitatif. Bandung: Rosdakarya.

Marleni. 2013. Pola dan Etos Kerja Perempuan Dalam Industri Rumah Tangga di Jorong Cangkiang Nagari Batu Taba Kecamatan Ampek Angkek Kabupaten Agam. Thesis: Program Pasca Sarjana Universitas Negeri Padang.

Resmi, Setia. 2005. Gali Tutup Lubang Itu Biasa: Strategi Buruh Menanggulangi Persoalan dari Waktu ke Waktu. Bandung: Yayasan Akatiga. 
Ramadhan, Hasan. 2013. "Peran Perempuan dalam Perekonomian". Jurnal Perempuan. (http://www.jurnalperempuan.org, access by 10 Juni 2016)

Santi, Sarah. 2007. Perempuan Dan Kemiskinan: Pembangunan, Kebijakan, dan Feminisme Kemiskinan. Forum Ilmiah Indonesia: Journal Vol.4 No. 1 Januari 2007.

Sprradley, James. 1997. Metode Etnografi. Yogyakarta: Tiara Wacana.

Suharto, E. 2009. Kemiskinan dan Perlindungan Sosial di Indonesia. Bandung: Alfabeta.

Suparlan, Parsudi. 1995. Kemiskinan di Perkotaan. Jakarta: Yayasan Obor.

Susilawati, Nora. 2003. Sosiologi Pedesaan, Learning Materials. UNP.

Syukur, Abdul. 2010. Peran Isteri dalam Menunjang Perekonomian Keluarga: Studi Tentang Keluarga Matrifokal Nelayan Samudera di Kelurahan Pulau Tidung Kecamatan Kepulauan Seribu Selatan, Kabupaten Administrasi Kepulauan Seribu provinsi DKI Jakarta. Tesis: Universitas Indonesia.

Setiadi, Elly. M. 2011. Pengantar Sosiologi. Jakarta: Kencana

Tambunan, Tulus. 2001. Perekonomian Indonesia: Teori dan Temuan Empiris. Jakarta: Ghalia Indonesia.

Zaitunah, Subhan. 2004. Kekerasan Terhadap Perempuan. Pustaka Pesanteren. Yokyakarta 